Article

\title{
Novel Poly(ester urethane urea)/Polydioxanone Blends: Electrospun Fibrous Meshes and Films
}

\author{
Kiran R. Adhikari ${ }^{1,2}$, Inessa Stanishevskaya ${ }^{3}$, Pablo C. Caracciolo ${ }^{4}\left(\mathbb{C}\right.$, Gustavo A. Abraham ${ }^{4}(\mathbb{C}$ \\ and Vinoy Thomas $2,5, *$ (D) \\ 1 Department of Physics, University of Alabama at Birmingham, Birmingham, AL 35294, USA; \\ kiranraj@uab.edu \\ 2 Center for Nanoscale Materials and Biointegration (CNMB), University of Alabama at Birmingham, \\ Birmingham, AL 35294, USA \\ 3 Rensselaer Polytechnic Institute, Troy, NY 12180, USA; Inessa.stanish@gmail.com \\ 4 Instituto de Investigaciones en Ciencia y Tecnología de Materiales, INTEMA (UNMdP-CONICET), \\ Av. Juan B. Justo 4302, B7608FDQ Mar del Plata, Argentina; pcaracciolo@fi.mdp.edu.ar (P.C.C.); \\ gabraham@fi.mdp.edu.ar (G.A.A.) \\ 5 Department of Materials Science and Engineering, University of Alabama at Birmingham, \\ Birmingham, AL 35294, USA \\ * Correspondence: vthomas@uab.edu; Tel.: +1-(205)-975-4098
}

Citation: Adhikari, K.R.; Stanishevskaya, I.; Caracciolo, P.C.; Abraham, G.A.; Thomas, V. Novel Poly(ester urethane urea)/Polydioxanone Blends: Electrospun Fibrous Meshes and Films. Molecules 2021, 26, 3847. https://doi.org/10.3390/ molecules 26133847

\section{Academic Editors: Juan}

Luis Vivero-Escoto and Miguel Mendez-Rojas

Received: 29 April 2021

Accepted: 19 June 2021

Published: 24 June 2021

Publisher's Note: MDPI stays neutral with regard to jurisdictional claims in published maps and institutional affiliations.

Copyright: (c) 2021 by the authors. Licensee MDPI, Basel, Switzerland. This article is an open access article distributed under the terms and conditions of the Creative Commons Attribution (CC BY) license (https:/ / creativecommons.org/licenses/by/ $4.0 /)$.
Abstract: In this work, we report the electrospinning and mechano-morphological characterizations of scaffolds based on blends of a novel poly(ester urethane urea) (PHH) and poly(dioxanone) (PDO). At the optimized electrospinning conditions, $\mathrm{PHH}, \mathrm{PDO}$ and blend $\mathrm{PHH} / \mathrm{PDO}$ in Hexafluroisopropanol (HFIP) solution yielded bead-free non-woven random nanofibers with high porosity and diameter in the range of hundreds of nanometers. The structural, morphological, and biomechanical properties were investigated using Differential Scanning Calorimetry, Scanning Electron Microscopy, Atomic Force Microscopy, and tensile tests. The blended scaffold showed an elastic modulus ( $5 \mathrm{MPa})$ with a combination of the ultimate tensile strength $(2 \pm 0.5 \mathrm{MPa})$, and maximum elongation $(150 \% \pm 44 \%)$ in hydrated conditions, which are comparable to the materials currently being used for soft tissue applications such as skin, native arteries, and cardiac muscles applications. This demonstrates the feasibility of an electrospun $\mathrm{PHH} / \mathrm{PDO}$ blend for cardiac patches or vascular graft applications that mimic the nanoscale structure and mechanical properties of native tissue.

Keywords: polyurethane urea; nanostructure; electrospinning

\section{Introductions}

Tissue regeneration, replacement, or repair of the damaged tissues, organs, or body structures is the major goal of tissue engineering [1]. With the scaffold being a major component of tissue engineering, mimicking closely the morphological, mechanical, and functional properties of native extracellular matrices (ECM) has attracted a great deal of attention in the fabrication of scaffolds for tissue regeneration [2-12]. Electrospinning is an enabling nanofabrication technique for creating nanofibrous tissue scaffolds having an extracellular matrix-like environment with tailored properties for tissue engineering and drug delivery applications [6,13-19]. The process of electrospinning has previously been described in detail [20,21], however, in short, it is a process of drawing fibers from viscoelastic fluid in which an electromagnetic field created by a high-voltage source causes the charged viscoelastic polymer solution-drop to jet towards a grounded surface and deposit as a non-woven fibrous mesh after undergoing a whipping instability motion. Fibers with diameters in the range from several micrometers down to less than $100 \mathrm{~nm}$ can be produced, and some studies reported the diameter of electrospun fibers to be as low as $10 \mathrm{~nm}[22,23]$. Collagens, a major protein component of ECM found in both soft and hard tissues, are in the form of fibers with diameters in the range of 50 to $500 \mathrm{~nm}$ [24]. Therefore, 
nanofibers are only synthetic analogs to native ECM and cells whose behavior are more similar physiologically on these biomimetic meshes [25]. Moreover, the manufacturing control over the diameter and pore size of these mesh structures in electrospun fibers and meshes provides an extra degree of flexibility for tissue engineering applications. This control over the fibrous structures and their diameter can be achieved by a myriad of control mechanisms over the experimental parameters and a range of material choices during the electrospinning process [26].

The choice of scaffolding materials is as important as the fabrication process. Among the various materials employed for tissue engineering scaffolds, synthetic biodegradable polyesters such as polycaprolactone (PCL), polyglycolide (PGA), polylactide (PLA), and their copolymers have drawn considerable attention due to their processibility and proven use as absorbable suture materials [27-29]. These classical aliphatic polyesters and their copolymers are relatively stiff and may not be very well-suited for the engineering of soft and flexible tissues. Moreover, in vivo study of pure PCL-based small-diameter vascular grafts in rat systemic circulation revealed that foci of chondroid metaplasia were located in the neointima of all implanted grafts after 6 weeks [30]. This study suggested the local hypoxia accompanied by the acidic degradation products is suspected to be the stimulus for overexpression of transforming growth factor-beta 1 (TGF- $\beta 1$ ) from the smooth muscle cells (SMCs) and/or endothelium to induce chondroid metaplasia and these metaplastic areas were found to be calcified after 24 weeks.

The scaffolds intended for use in cardiac and vascular tissue regeneration must undergo repeated cyclic flexing in accordance with the systole and diastole phases of the cardiac cycle. Scaffolds fabricated from elastomeric materials can withstand the action of repeated stress and load and undergo an elastic recovery with little or no hysteresis. Segmented poly(urethane)s and poly(ester urethane urea)s (PEUU) are elastomeric polymers with favorable biocompatibility, soft-tissue mechanical properties, controlled degradation characteristics, and have extensive diverse structure and properties [31,32]. Degradation rates of PEUU can be accelerated to levels relevant for tissue engineering applications by introducing hydrolytically labile components into either the hard or soft segments of the polymer backbone [33,34]. In previous studies, Caracciolo et al. [35,36] have reported the preparation, characterization of thermal and mechanical properties, and in vitro biological properties of aliphatic segmented poly(ester urethane urea) (PHH) based on poly(E-caprolactone) (PCL), hexamethylene diisocyanate (HDI), and novel aliphatic chain extenders containing urea functional groups. The advantage of using this material in bio-applications is well-documented in the literature. The tissue compatibility of these materials is due to their excellent protein adsorption and cellular interaction at the interface $[35,37]$. In this work, $\mathrm{PHH}$ was blended with polydioxanone (PDO) and electrospun into fibrous scaffolds.

PDO is a semi-crystalline, biodegradable polymer commonly used as bioabsorbable suture material in clinical use, whose mechanical strength is capable of withstanding pulsatile blood flow. It also possesses shape memory, which is a very attractive material for vascular graft applications due to its various advantageous characteristics like its ease of handling, ease of suture placement, suture retention, and biocompatibility [38-40]. Moreover, the presence of an ether bond and an additional methylene group in its molecular structure gives polydioxanone more flexibility than PGA and PLA. Polydioxanone and its copolymer materials (MonoFlex) have shown a reduction of $~ 50 \%$ of strength between 4 and 6 weeks in vivo and is absorbed in about 6 months with minimal inflammatory reactions with lower absorption rates than sutures composed of PGA and poly (glycolic-colactic acid) (PGLA) [41]. Previously, electrospun hybrid vascular scaffolds of blends of PDO with vascular proteins such as gelatin and/or elastin [38,39,42] have been studied. Recently, the application of PDO has been extensively studied by various researchers. Goonoo et al. reported the fabrication and drug delivery applications of PDO-based electrospun mats. [43] They reported the application of the shape memory property of PDO materials for the fabrication of ECM mimicking mat structures. In another study, Song et al. reported 
the aligned electrospun fibers mats fabricated with PDO as core material and laminin as shell materials and reported their application in neurogenesis [44]. In this study, we electrospun and compared the properties of fibrous scaffolds and the corresponding nonporous film counterparts of $\mathrm{PHH} / \mathrm{PDO}$ blends. Using the blends of these materials will enable us to control the mechano-physical properties as well as the degradation behaviors. The electrospun fibrous mats were prepared in this study keeping a wide variety of applications in mind. The non-aligned fibrous structure in the mats is reported to be applicable in applications like vascular grafts, skin implants, etc., whereas the aligned fiber in the mat is reported to be applicable in neural tissue regeneration or applications where aligned tissue structure is warranted [45-49]. The application of elastomeric polymers for cardiac patch application has been widely reported over the year. Mousa et al., in their study, reported the fabrication and three-layered nanofibrous patch and reported the patches with adequate mechanical properties and showed the biocompatibility [50]. Very recently, Beck et al. has shown the PCL- and PU-based blend to fabricate the cardiac patch and has shown excellent cell infiltration [51]. In our study, e-scaffolds were characterized for their biomechanical properties in both dry and hydrated conditions and structural and morphological properties for soft-tissue engineering applications so that the electrospun fiber and mesh structure mimic the properties of the native tissue structures. In this paper, we compare the mechanical behavior, porosity, and PBS uptake of the electrospun mat to their non-porous counterpart films, as electrospun mats have been shown to have ECM-mimicking structure, which is very vital in the biomedical application.

\section{Materials and Methods}

\subsection{Polyurethane Synthesis}

The PHH used for this study was synthesized from PCL, hexamethylene diisocyanate (HDI), and an aliphatic diurea-diol chain extender (AE-H-AE) based on 2-aminoethanol (AE), according to previously reported procedures $[35,36]$. The nomenclature for the poly(ester urethane urea) for this study is written as PHH as adopted from these studies based on the chain extender used for modifying the poly(ester urethane urea).

\subsection{Scaffolds and Films Preparation}

Electrospun scaffolds were fabricated by the process of electrospinning solutions using PHH, PDO, and a blend of PHH and PDO in a 1:1 ratio in 1,1,1,3,3,3-hexafluoro-2-propanol (HFIP). The electrospinning system consisted of a syringe pump, a high voltage supply, and a rotating mandrel for the collection of fibers. Process parameters were optimized for the PHH solution $(25 \% w / v)$ and the PHH/PDO blend $(15 \% w / v)$, whereas the parameters for the PDO $(15 \% w / v)$ solution were taken from the previous study [52].

For all the solutions, a positive voltage of $25 \mathrm{kV}$ was applied to the syringe by the power supply and they were all delivered through a 25-gauge blunt-tip syringe needle. The PHH and PDO solutions were dispensed at a constant flow rate of $1 \mathrm{~mL} / \mathrm{h}$ using a syringe pump (PHD2000, Harvard Apparatus, MA, USA), whereas the PHH/PDO blend was supplied at $1 \mathrm{~mL} / \mathrm{h}$.

For the electrospun mat with non-aligned fiber distribution, the collecting mandrel (stainless-steel rod) of $4 \mathrm{~mm}$ outer diameter was positioned $25 \mathrm{~cm}$ away from the tip of the needle and the rotation rate was $400 \mathrm{rpm}$.

For the electrospun mat with aligned fiber distribution, the aluminum collecting mandrel of outer diameter $50 \mathrm{~mm}$ was positioned $25 \mathrm{~cm}$ away from the tip of the needle and the rotation rate was $2000 \mathrm{rpm}$.

All of these scaffolds were desiccated under a vacuum for $48 \mathrm{~h}$ at room temperature to ensure the removal of residual solvent.

Non-porous films of $\mathrm{PHH}, \mathrm{PDO}$, and $\mathrm{PHH} / \mathrm{PDO}$ blend were prepared by solution casting from HFP $(15 \% w / v)$ onto siliconized Petri dishes. The solvent gets evaporated and dried films were finally desiccated under a vacuum for $48 \mathrm{~h}$. 


\subsection{Structural Morphological and Chemical Characterizations}

The scaffolds were characterized for physio-chemical, structural, and morphological properties. The morphological characterization of the electrospun scaffolds was carried out by imaging using a scanning electron microscope (SEM; Philips 515). The scaffolds were first sputter-coated with gold to ensure electrical conductivity. The images were analyzed with ImageJ software to determine average fiber diameter and diameter distribution.

Individual fibers of $\mathrm{PHH}, \mathrm{PDO}$, and $\mathrm{PHH} / \mathrm{PDO}$, as well as corresponding polymer films, were also examined under an atomic force microscope (AFM; TopoMetrix Explorer, Santa Clara, CA, USA) in contact mode to further investigate surface features. Images were examined with SPM-Lab software to calculate average fiber roughness and film roughness from $10 \times 10 \mu \mathrm{m}$ images.

Differential scanning calorimetry (DSC; TA Instruments Q100) was performed on the electrospun samples to determine the glass transition temperature $\left(T_{g}\right)$, the crystallization temperature $\left(T_{c}\right)$, and the melting temperature $\left(T_{m}\right)$, as well as their crystallinity. Percent crystallinity was determined through the ratio of enthalpy of fusion $\left(\Delta H_{f}\right)$ of the sample to the enthalpy of fusion for $100 \%$ crystallinity $\left(\Delta H_{f}^{0}\right)$ :

$$
\text { Crystalinity }(\%)=\frac{\Delta H_{f}}{\Delta H_{f}^{0}} \times 100 \%
$$

The scaffold porosity was also calculated from the apparent density measurements. Three samples of each scaffold were cut into $5 \times 5 \mathrm{~mm}$ squares and then weighed. Thickness was measured through a thermomechanical analysis instrument used for measuring the thermal expansion of films (TMA; TA Instruments Q400) by measuring the thickness at five various points on each scaffold sample and then averaging the thicknesses. Porosity was estimated by the following equation:

$$
\text { Porosity }=\left\{1-\frac{\text { Apparent density of the scaffold }}{\text { Bulk density of the scaffold }}\right\}
$$

Apparent density measurement was done using the following formula $[53,54]$

$$
\text { Apparent density of scaffolds }=\frac{\text { mass of the electrospun matrix }}{\text { thickness } \times \text { area }}
$$

The overall porosity was determined by taking the average porosity of three samples. Phosphate-Buffered Saline (PBS) uptake was also determined to evaluate the hydrophilicity of the electrospun scaffolds. Scaffold samples were initially weighed $\left(w_{1}\right)$ and then were immersed in phosphate-buffered saline solution (PBS; $\mathrm{pH}=7.4$ ) for a period of $24 \mathrm{~h}$, after which they were taken out of the PBS, wiped dry with a tissue paper, and immediately weighed $\left(w_{2}\right)$. The percentage of PBS uptake was calculated using the following equation:

$$
\text { PBS uptake }(\%)=\frac{w_{2}-w_{1}}{w_{1}}
$$

For chemical analysis of the samples, FTIR was performed using Thermo Nicolet nexus 4700 FT-IR spectrometers on randomly electrospun samples.

\subsection{Biomechanical Evaluation}

Electrospun specimens with randomly oriented fibers were cut into samples of $30 \mathrm{~mm}$ length, $2.5 \mathrm{~mm}$ width, and an average thickness of $165 \pm 20.4 \mu \mathrm{m}$ for dry samples, and an average thickness of $124 \pm 9.3 \mu \mathrm{m}$ for hydrated samples. Hydration was carried out by immersing the samples in PBS at room temperature for $24 \mathrm{~h}$. This treatment showed no visible influence on the appearance and dimensions of the samples. Uniaxial tensile properties were measured using a BOSE Electroforce LM1 Test Bench equipped with a 22 N load cell (Bose Corporation-ElectroForce Systems Group, Eden Prairie MN, USA) 
at a crosshead speed of $0.1 \mathrm{~mm} / \mathrm{s}$. The ultimate tensile strength, yield strength, Young's modulus, and elongation at break were obtained from the stress-strain curves.

\section{Results and Discussion}

\subsection{Structural and Morphological Characterization}

The scaffolds were characterized physio-chemically and morphologically. SEM images of non-aligned electrospun $\mathrm{PHH}, \mathrm{PDO}$ and the $\mathrm{PHH} / \mathrm{PDO}$ blend scaffold are illustrated in Figure 1. The scaffolds prepared at the optimized electrospinning parameters show randomly oriented fiber meshes with a relatively narrow distribution of fiber diameters and without imperfections such as small polymer beads.


Figure 1. SEM images of the surface morphologies of non-aligned electrospun (a) PDO, (b) PHH/PDO, (c) PHH, and (d) diameter distribution of fibers.

The electrospun PDO, PHH/PDO blend, and PHH scaffolds exhibited the diameter distribution with average values of $648 \pm 157,758 \pm 297$, and $1056 \pm 590 \mathrm{~nm}$, respectively, which is comparable to the typical diameters of collagen fibers found in natural arteries. The fiber diameters are comparable to the typical diameters of collagen fibers found in natural arteries (50 to $500 \mathrm{~nm}$ ) [24]. Since the topology of electrospun scaffolds closely mimics that of the native extracellular matrix, these biomimetic matrices facilitate cell attachment, support cell growth, and regulate cell differentiation $[2,6,25]$. The SEM image of electrospun PHH reveals the physical bonding and fusing of fibers. The effect of physical 
bonding on the mechanical and morphological characteristics has been studied by various researchers and is reported to enhance the physical properties of the fibrous mat [55-57].

SEM images of aligned electrospun PHH, PDO, and the PHH/PDO blend scaffold are illustrated in Figure 2.


Figure 2. SEM images of the surface morphologies of aligned electrospun (a) PDO, (b) PHH/PDO, (c) PHH, and (d) diameter distribution of fibers.

The diameter analysis of the aligned electrospun fibers for PDO, PDO/PHH, and $\mathrm{PHH}$ exhibited a diameter distribution with an average value of $579 \pm 255,855 \pm 600$, and $900 \pm 488 \mathrm{~nm}$, respectively. All of these fibers are oriented in the direction of the mandrel rotation direction.

Although the stretching and recoiling of the electrospun mat were not studied in this study, the thicker diameter of the individual fibers in the mat of the electrospun PHH can be attributed to the recoil of the fibers making the diameter larger.

AFM (contact mode) was performed on the PHH, PDO, and PHH/PDO individual fibers, as well as on the solvent cast films of these polymer solutions. Figure 3 shows the AFM surface morphology for the films of PHH, PDO, and the PHH/PDO blend. 


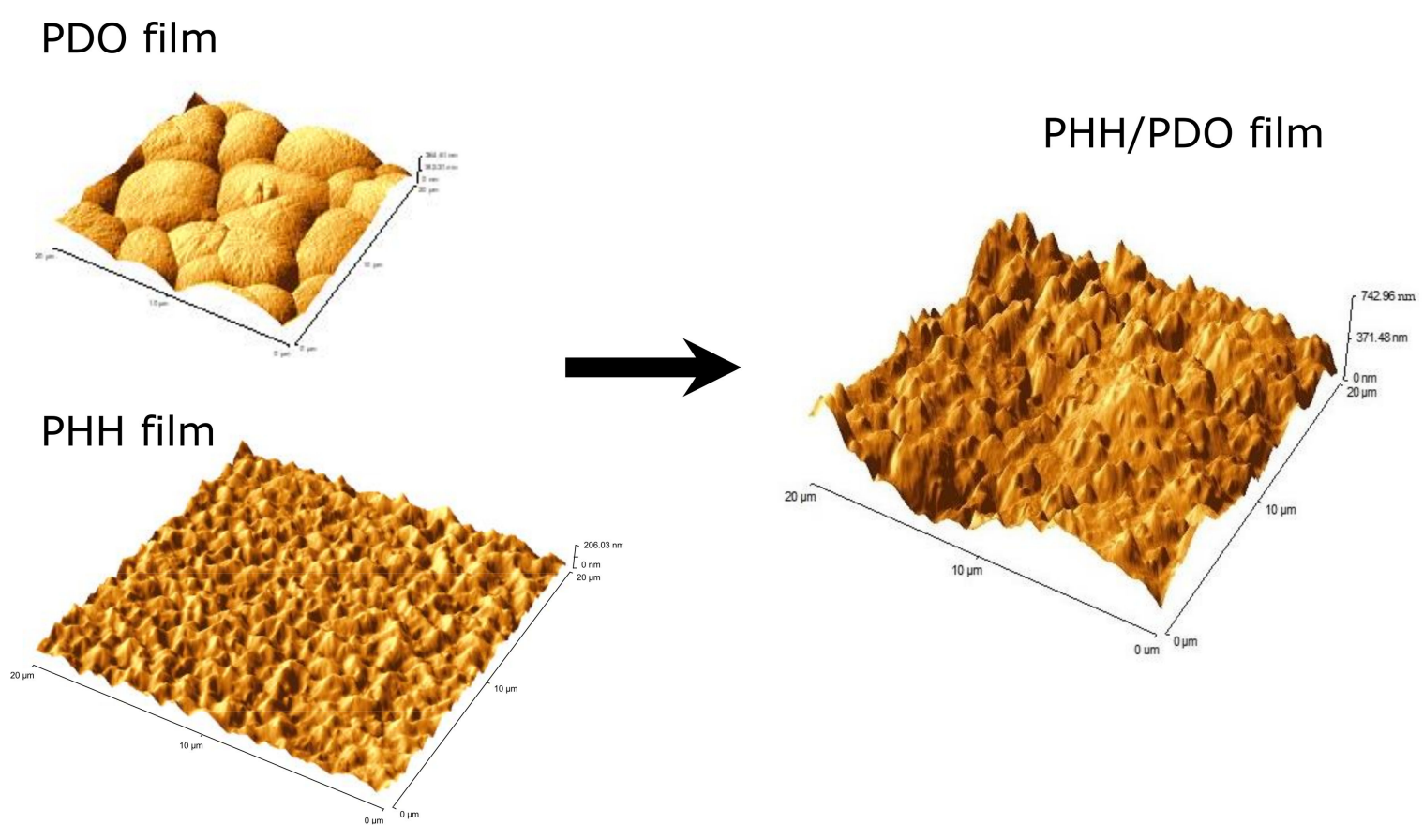

Figure 3. AFM image of $\mathrm{PDO}, \mathrm{PDO} / \mathrm{PHH}$, and $\mathrm{PHH}$ films.

Amongst the film systems, $\mathrm{PHH}$ demonstrated the smallest roughness (RMS) of $29.70 \mathrm{~nm}$, whereas PHH/PDO had the greatest of $156.32 \mathrm{~nm}$. The PDO film displayed the characteristic spherulitic surface morphology, which is attributed to the high crystallinity of this polymer, and had an intermediate RMS roughness of $55.37 \mathrm{~nm}$.

Figure 4 depicts the AFM images of the individual fibers. PHH fibers had a roughness (RMS) of $154.10 \mathrm{~nm}, \mathrm{PHH} / \mathrm{PDO}$ fibers had a roughness of $257.32 \mathrm{~nm}$, while the PDO fibers exhibited the greatest roughness of $788.81 \mathrm{~nm}$. A larger change in the roughness of the PDO fibers can be attributed to the increased surface waviness of the fibrous materials due to high crystallinity. It should be noted that a high roughness of a material can be beneficial in tissue engineering because it increases the surface area on which cells can attach to and proliferate.

Figure 5 represents the spectra of the electrospun $\mathrm{PHH}, \mathrm{PDO}$, and $\mathrm{PHH} / \mathrm{PDO}$ blends. The peak centered around $3300 \mathrm{~cm}^{-1}$ in the $\mathrm{PHH}$ spectra represents the $\mathrm{N}-\mathrm{H}$ stretching in the hydrogen-bonded urea group, which is the signature peak in the polyurethanes. The large peak at around $1700 \mathrm{~cm}^{-1}$ in this spectra is associated with carbonyl groups of PCL soft segments and urethane groups in $\mathrm{PHH}$ [35]. The characteristic C-O-C is seen in the spectra of $\mathrm{PDO}$ around $1125 \mathrm{~cm}^{-1}$ and other $\mathrm{C}-\mathrm{H}, \mathrm{C}=\mathrm{O}$, and $\mathrm{O}-\mathrm{H}$ bands associated with the PDO are consistent with the spectra reported by Song et al. [44]. The spectrum for the blend presents peaks associated with both materials. 


\section{$\mathrm{PHH}$ fiber}
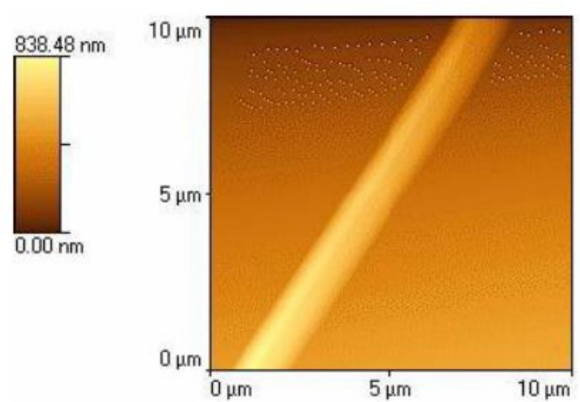

PDO fiber
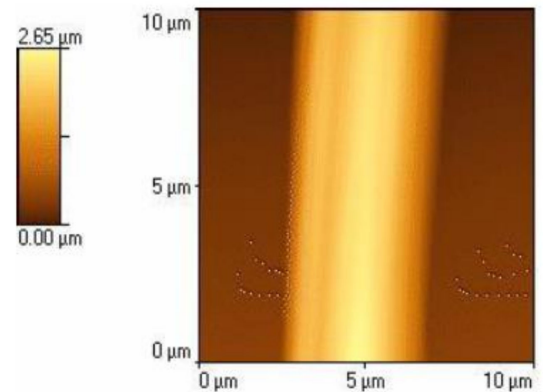

PHH/PDO fiber
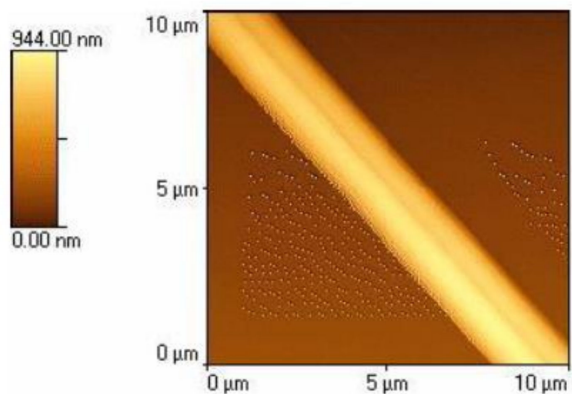

Figure 4. AFM image of a single fiber of PHH, PDO, and PHH/PDO films.



Figure 5. FTIR spectra of the samples.

\subsection{Crystallinity, Porosity, and PBS Uptake by the Electrospun Mats}

Comparison of crystallinity, porosity, and PBS uptake of the electrospun scaffolds is represented in Table 1. DSC experiments were performed on PHH, PDO, and blend 
scaffolds. The obtained results showed that $\mathrm{PHH}$ had a glass transition temperature, $\mathrm{T}_{\mathrm{g}}=-60{ }^{\circ} \mathrm{C}$, crystalline temperature, $\mathrm{T}_{\mathrm{C}}=4.3^{\circ} \mathrm{C}$, and melting point, $\mathrm{T}_{\mathrm{m}}=39.9^{\circ} \mathrm{C}$. $\mathrm{PDO}$ had a $\mathrm{T}_{\mathrm{g}}=-20{ }^{\circ} \mathrm{C}, \mathrm{T}_{\mathrm{c}}=52.4{ }^{\circ} \mathrm{C}$, and $\mathrm{T}_{\mathrm{m}}=106.4{ }^{\circ} \mathrm{C}$, and the blend had a $\mathrm{T}_{\mathrm{g}}=-60^{\circ} \mathrm{C}$, $\mathrm{T}_{\mathrm{c}}=-5^{\circ} \mathrm{C}$, and $\mathrm{T}_{\mathrm{m}}=103.4^{\circ} \mathrm{C}$. Since PHH, PDO and the PHH/PDO blend have crystalline characteristics, the heat of fusion was determined to be $13.7,81.27$, and $36.11 \mathrm{~J} \mathrm{~g}^{-1}$, respectively. The DSCs are depicted in Figure 6.

Table 1. Comparison of crystallinity, porosity, and PBS uptake by the scaffolds.

\begin{tabular}{cccc}
\hline Sample & Crystallinity (\%) & Porosity (\%) & PBS Absorption (\%) \\
\hline ePHH & 11.8 & $66.4 \pm 3.8$ & $197.1 \pm 12.3$ \\
ePDO & 57.2 & $79.2 \pm 2.7$ & $503.3 \pm 34.5$ \\
ePHH/PDO & 25.6 & $71.7 \pm 5.3$ & $852.5 \pm 17.6$ \\
\hline
\end{tabular}

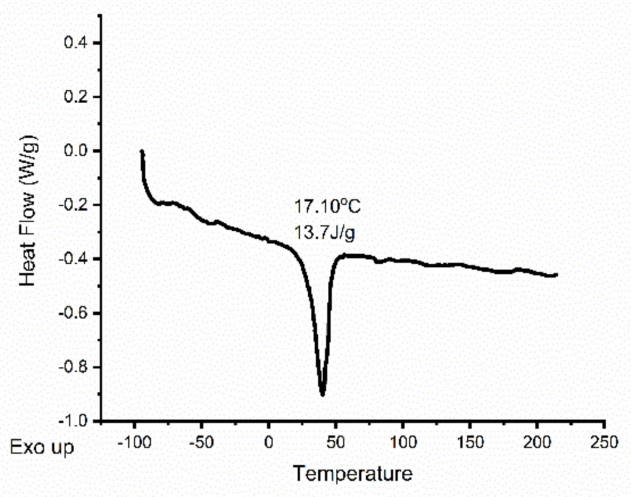

(a)

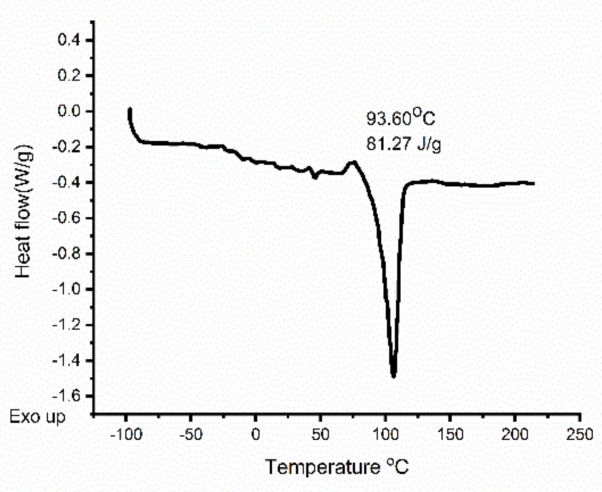

(b)

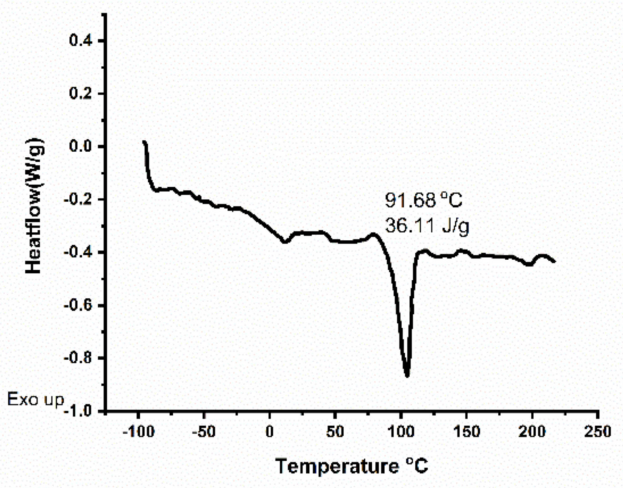

(c)

Figure 6. DSC images of (a) PHH (b) PDO and (c) PHH/PDO electrospun mats.

The presence of two Tg values for the 1:1 PHH/PDO blend in Figure $6 \mathrm{c}$ indicated only partial miscibility in 1:1 composition. This is in accordance with a reported miscibility study on biodegradable poly(butylene succinate) (PBS)/polydioxanone blends [58]; where $50 \%$ PDO in blend with PBS indicated semi-miscibility and more than 50\% PDO indicated miscible blends. However, PDO increased to $75 \%$ in an electrospun blend with proteins degraded to show 30\% weight loss within 30 days in a previous study [42]. Therefore, we opted for a 50\% PDO with a 50\% PHH blend system to prevent the possibility of the fast degradation in our electrospun scaffold blends.

The heat of fusion of an infinite PDO crystal, which has been determined to be $142.1 \mathrm{~J} \mathrm{~g}^{-1}[42,58]$, was used to calculate a crystallinity of $57.2 \%$ for the neat PDO. The degree of crystallinity of electrospun $\mathrm{PHH}$, calculated taking into account the melting 
enthalpy for $100 \%$ crystalline PCL $\left(148.05 \mathrm{~J} \mathrm{~g}^{-1}\right)$ [59] was $11.8 \%$. The blend exhibited a $25.6 \%$ crystallinity. The enthalpy for $100 \%$ crystallinity for the blend is calculated by averaging the enthalpy of both the constituents. The measured values of the percentage crystallinity and porosity of the blend lie in between those for individual fiber meshes.

Interestingly, the PBS uptake ability of the electrospun PHH/PDO blend scaffolds was much greater than that of the electrospun PDO-only scaffold and that of the electrospun PHH-only scaffold. The high value of the PBS absorption in electrospun PHH/PDO scaffolds is linked to a favorable combination of interconnected porosity (higher than in $\mathrm{PHH}$ ) and decreased crystallinity due to the distribution of $\mathrm{PHH}$ in the $\mathrm{PHH} / \mathrm{PDO}$ blend as observed by AFM. Because of the high degree of hydrophobicity and non-porous nature, the corresponding films of $\mathrm{PHH}, \mathrm{PDO}$, and $\mathrm{PHH} / \mathrm{PDO}$ absorbed less than $1 \%$ PBS within $24 \mathrm{~h}$.

\subsection{Mechanical Characterization}

Table 2 represents the results from the mechanical characterization of the electrospun mat and the films at dry and wet conditions.

Table 2. Mechanical characterization, Comparison of tensile properties of PHH, PDO, and PHH/PDO scaffolds and films in dry and hydrated conditions.

\begin{tabular}{ccccccc}
\hline Polymers & UTS (MPa) & & Young's Modulus & & \multicolumn{2}{c}{$\begin{array}{c}\text { Elongation at } \\
\text { Break (\%) }\end{array}$} \\
\hline & Dry & Wet & Dry & Wet & Dry & Wet \\
\hline PHH film & $5.3 \pm 0.5$ & $4.5 \pm 0.68$ & $10.0 \pm 1.5$ & $7.8 \pm 1.9$ & $291.0 \pm 44$ & $259.0 \pm 94$ \\
\hline PDO film & $5.6 \pm 1.3$ & $4.4 \pm 0.89$ & $44.4 \pm 7.8$ & $26.7 \pm 2.2$ & $28.6 \pm 8.2$ & $13.4 \pm 2.3$ \\
\hline PHH/PDO film & $5.7 \pm 1.1$ & $3.2 \pm 1.1$ & $10.5 \pm 1.2$ & $23.5 \pm 0.1$ & $71.4 \pm 21.5$ & $53.6 \pm 37.9$ \\
\hline ePHH & $1.1 \pm 0.2$ & $0.7 \pm 0.3$ & $1.0 \pm 0.1$ & $1.7 \pm 0.7$ & $176.3 \pm 13.8$ & $90.4 \pm 19.2$ \\
\hline ePDO & $3.7 \pm 0.5$ & $2.5 \pm 0.2$ & $9.5 \pm 1.0$ & $7.1 \pm 0.1$ & $139.2 \pm 28.1$ & $150.0 \pm 15.6$ \\
\hline ePHH/PDO & $2.2 \pm 0.4$ & $2.0 \pm 0.5$ & $4.8 \pm 0.7$ & $3.9 \pm 1.1$ & $73.4 \pm 15.5$ & $150.2 \pm 44.4$ \\
\hline
\end{tabular}

The electrospun PDO mesh scaffolds exhibited a tensile strength (UTS) of $3.7 \pm 0.5 \mathrm{MPa}$, Young's modulus of $9.5 \pm 1.0 \mathrm{MPa}$, and an elongation percentage at the break of $139.2 \% \pm 28.1 \%$ in dry conditions. Under physiological hydrated conditions, ePDO experienced a 32.4\% decrease in UTS, a 25.3\% decrease in Young's modulus, and a 7.8\% increase in elongation at break. The addition of PHH to PDO changed the UTS to $2.2 \pm 0.4 \mathrm{MPa}$ in dry conditions and $2.0 \pm 0.5 \mathrm{MPa}$ in hydrated conditions, values that are intermediates between those of the two pure scaffolds. The Young's modulus of the PHH/PDO blend was also in between the values of the pure scaffolds under both dry and hydrated conditions. The mechanical properties, in general, were found to decrease, which makes sense as water acting as the plasticizer and hence reducing the mechanical properties of polymer materials. As for the elongation at break, the blend had the lowest elongation in dry conditions and approximately the same value as the PDO scaffold under hydrated conditions. The value for elongation at break decreases in the hydrated condition for all cases except for electrospun mats with PDO, and that of the blend $\mathrm{PHH} / \mathrm{PDO}$. This is a very interesting result and could be attributed to the way crystalline PDO in fiber form absorbs water but this result needs further investigations. The mechanical properties of electrospun $\mathrm{PHH}$ and $\mathrm{PHH} / \mathrm{PDO}$ scaffolds are comparable to those of elastomeric polymeric materials reported for cardiac tissue engineering in the literature. For example, Chen et al. have fabricated an elastomeric heart patch from polyglycerol sebacate (PGS) with modulus ranging from 0.056 to $1.2 \mathrm{MPa}$ [60]. In another study, Fujimoto et al. [61] have used an elastomeric poly(ester urethane urea) (PEUU) scaffold with UTS of $0.78 \mathrm{MPa}$ and a strain failure of $157 \%$ as a cardiac patch and implanted it in the sub-acute infracts developed after coronary ligation in the rat model. They have observed not only plenty of smooth muscle cells with 
matured contractile behavior in PEUU-implanted animals, indicating better myocardial compliance, but significantly more amounts of basic fibroblast growth factor (bFGF) and vascular endothelial growth factor (VEGF) being produced around the vessels in the PEUU patch group than in the infraction control group.

Elastomeric cardiac patches can easily recover from deformations and sustain the cyclic strain of the heart under physiological conditions due to their inherent intrinsic elasticity. However, only limited studies using nanofibrous polyurethane scaffolds have been reported as tissue engineering scaffolds so far [62-64]. In an in vivo rabbit study using a biodegradable poly(ester urethane) for up to 63 days, Henry et al. [62] have shown that highly porous electrospun poly(urethane) scaffolds evoked a superior host tissue and angiogenic response compared to a polyurethane film. Rockwood et al. [63] have shown that cultured cardiomyocytes in vitro on electrospun polyurethane scaffolds decreased the expression of atrial natriuretic peptide, a molecular marker that shows decreasing expression during ventricular cell maturation, than in those grown on tissue culture polystyrene. In another study, a PEUU based on a poly ( $\varepsilon$-caprolactone) diol soft segment and a hard segment of an aliphatic diisocyanate and putrescine chain extender was found to be cytocompatible to vascular muscle cells and processed into 'cells-micro integrated scaffolding' by electrospraying cell-suspension concurrently with electrospinning of PEUU fibers [64]. PHH is a PCL (soft segment)-based biodegradable PEUU having HDI with a novel chain extender (AE-H-AE) (hard segment) possessing soft tissue-like mechanics [36]. Studies on protein adsorption, platelet adhesion, and thrombus formation $[35,36]$ showed excellent blood compatibility of the PHH for potential blood-contacting applications.

\section{Conclusions}

In this study, we fabricated and tested an electrospun PHH/PDO blend (1:1) scaffold and compared the test results with those of pure PHH and PDO scaffolds. At the optimized conditions $(V=25 \mathrm{kV}, v=1 \mathrm{~mL} / \mathrm{h}, h=25 \mathrm{~cm})$ electrospinning of $15 \%(w / v) \mathrm{PHH} / \mathrm{PDO}$ in HFIP solution yielded bead-free random blended micro/nanofibers with an average diameter of $758 \pm 297 \mathrm{~nm}$ and $71.7 \% \pm 5.3 \%$ porosity. The blended scaffold showed a low elastic modulus $(\sim 5 \mathrm{MPa})$ with a combination of the ultimate tensile strength $(2 \pm 0.5 \mathrm{MPa})$, and a maximum elongation $(150 \% \pm 44 \%)$ in hydrated conditions. These results are comparable to the characteristic tensile properties of cardiac or vascular tissues, and thus demonstrate the feasibility of electrospinning to fabricate a PHH/PDO blend cardiac patch that mimics the nanoscale structure and mechanical properties of native tissues. Detailed studies on the biodegradation behavior and cell-scaffold interactions of the present elastomeric scaffold should be undertaken in the future to warrant its potential use in this soft-tissue engineering.

Author Contributions: Conceptualization, V.T., K.R.A. and I.S.; methodology, V.T., K.R.A., I.S., P.C.C. and G.A.A.; software, K.R.A. and I.S.; validation, V.T.; formal analysis, K.R.A. and I.S.; investigation, K.R.A. and I.S.; resources, V.T., P.C.C. and G.A.A.; data curation, K.R.A., and I.S.; writing-original draft preparation, K.R.A. and I.S.; writing-review and editing, V.T., visualization, V.T. and K.R.A.; supervision, V.T.; project administration, V.T.; Funding acquisition, V.T. All authors have read and agreed to the published version of the manuscript.

Funding: This research was funded by the Alabama Department of Commerce and Community Affairs (ADECA) from the Alabama Research and Development Enhancement Fund for the Commercialization of small-diameter vascular grafts for dialysis access, and ANPCyT grant number PICT 2018-02334.

Institutional Review Board Statement: Not applicable.

Informed Consent Statement: Not applicable.

Data Availability Statement: The data presented in this study are available on request from the corresponding author. 
Acknowledgments: We would like to thank Bernabe Tucker for helping with the SEM imaging and Sunil Karna for helping with AFM imaging.

Conflicts of Interest: The authors declare no conflict of interest.

Sample Availability: Samples of the compounds are not available from the authors.

\section{References}

1. Garg, T.; Singh, O.; Arora, S.; Murthy, R.S.R. Scaffold: A Novel Carrier for Cell and Drug Delivery. Crit. Rev. Ther. Drug Carr. Syst. 2012, 29, 1-63. [CrossRef]

2. Stevens, M.M. Exploring and Engineering the Cell Surface Interface. Science 2005, 310, 1135-1138. [CrossRef] [PubMed]

3. Langer, R.; Tirrell, D.A. Designing materials for biology and medicine. Nat. Cell Biol. 2004, 428, 487-492. [CrossRef] [PubMed]

4. Zhang, S.; Gelain, F.; Zhao, X. Designer self-assembling peptide nanofiber scaffolds for 3D tissue cell cultures. Semin. Cancer Biol. 2005, 15, 413-420. [CrossRef] [PubMed]

5. Liao, S.; Li, B.; Ma, Z.; Wei, H.; Chan, C.; Ramakrishna, S. Biomimetic electrospun nanofibers for tissue regeneration. Biomed. Mater. 2006, 1, R45-R53. [CrossRef] [PubMed]

6. Thomas, V.; Derrick, D.R.; Vohra, Y.K. Nanostructured Biomaterials for Regenerative Medicine. Available online: http:/ /www. eurekaselect.com/56585/article (accessed on 26 September 2019).

7. Goldberg, M.; Langer, R.; Jia, X. Nanostructured materials for applications in drug delivery and tissue engineering. J. Biomater. Sci. Polym. Ed. 2007, 18, 241-268. [CrossRef] [PubMed]

8. Ma, P.X. Biomimetic materials for tissue engineering. Adv. Drug Deliv. Rev. 2008, 60, 184-198. [CrossRef]

9. Jun, I.; Han, H.-S.; Edwards, J.R.; Jeon, H. Electrospun Fibrous Scaffolds for Tissue Engineering: Viewpoints on Architecture and Fabrication. Int. J. Mol. Sci. 2018, 19, 745. [CrossRef]

10. Naahidi, S.; Jafari, M.; Logan, M.; Wang, Y.; Yuan, Y.; Bae, H.; Dixon, B.; Chen, P. Biocompatibility of hydrogel-based scaffolds for tissue engineering applications. Biotechnol. Adv. 2017, 35, 530-544. [CrossRef]

11. Iravani, S.; Varma, R.S. Plants and plant-based polymers as scaffolds for tissue engineering. Green Chem. 2019, $21,4839-4867$. [CrossRef]

12. Mabrouk, M.; Beherei, H.H.; Das, D.B. Recent progress in the fabrication techniques of 3D scaffolds for tissue engineering. Mater Sci. Eng. C 2020, 110, 110716. [CrossRef]

13. Sell, S.; Barnes, C.; Smith, M.; McClure, M.; Madurantakam, P.; Grant, J.; McManus, M.; Bowlin, G. Extracellular matrix regenerated: Tissue engineering via electrospun biomimetic nanofibers. Polym. Int. 2007, 56, 1349-1360. [CrossRef]

14. Sill, T.J.; Von Recum, H.A. Electrospinning: Applications in drug delivery and tissue engineering. Biomaterials 2008, 29, 1989-2006. [CrossRef]

15. Lim, S.H.; Mao, H.-Q. Electrospun scaffolds for stem cell engineering. Adv. Drug Deliv. Rev. 2009, 61, 1084-1096. [CrossRef]

16. Khalf, A.; Madihally, S.V. Recent advances in multiaxial electrospinning for drug delivery. Eur. J. Pharm. Biopharm. 2017, 112, 1-17. [CrossRef]

17. Pant, B.; Park, M.; Park, S.-J. Drug Delivery Applications of Core-Sheath Nanofibers Prepared by Coaxial Electrospinning: A Review. Pharmaceutics 2019, 11, 305. [CrossRef]

18. Chen, S.; Li, R.; Li, X.; Xie, J. Electrospinning: An enabling nanotechnology platform for drug delivery and regenerative medicine. Adv. Drug Deliv. Rev. 2018, 132, 188-213. [CrossRef]

19. Liu, X.; Yang, Y.; Yu, D.-G.; Zhu, M.-J.; Zhao, M.; Williams, G.R. Tunable zero-order drug delivery systems created by modified triaxial electrospinning. Chem. Eng. J. 2019, 356, 886-894. [CrossRef]

20. Burger, C.; Hsiao, B.S.; Chu, B. Nanofibrous Materials and their Applications. Annu. Rev. Mater. Res. 2006, 36, 333-368. [CrossRef]

21. Greiner, A.; Wendorff, J.H. Electrospinning: A Fascinating Method for the Preparation of Ultrathin Fibers. Angew. Chem. Int. Ed. 2007, 46, 5670-5703. [CrossRef]

22. Jian, S.; Zhu, J.; Jiang, S.; Chen, S.; Fang, H.; Song, Y.; Duan, G.; Zhang, Y.; Hou, H. Nanofibers with diameter below one nanometer from electrospinning. RSC Adv. 2018, 8, 4794-4802. [CrossRef]

23. Vollrath, F. Spider Silk: Thousands of Nano-Filaments and Dollops of Sticky Glue. Curr. Biol. 2006, 16, R925-R927. [CrossRef] [PubMed]

24. Elsdale, T.; Bard, J. Collagen Substrata for Studies on Cell Behavior. J. Cell Biol. 1972, 54, 626-637. [CrossRef] [PubMed]

25. Nisbet, D.R.; Forsythe, J.S.; Shen, W.; Finkelstein, D.I.; Horne, M. Review Paper: A Review of the Cellular Response on Electrospun Nanofibers for Tissue Engineering. J. Biomater. Appl. 2008, 24, 7-29. [CrossRef]

26. Stepanyan, R.; Subbotin, A.; Cuperus, L.; Boonen, P.; Dorschu, M.; Oosterlinck, F.; Bulters, M.J.H. Fiber diameter control in electrospinning. Appl. Phys. Lett. 2014, 105, 173105. [CrossRef]

27. Gunatillake, P.; Mayadunne, R.; Adhikari, R. Recent developments in biodegradable synthetic polymers. Biotechnol. Annu. Rev. 2006, 12, 301-347. [CrossRef]

28. Middleton, J.C.; Tipton, A.J. Synthetic biodegradable polymers as orthopedic devices. Biomaterials 2000, 21, 2335-2346. [CrossRef]

29. Shoichet, M.S. Polymer Scaffolds for Biomaterials Applications. Macromolecules 2010, 43, 581-591. [CrossRef] 
30. Pektok, E.; Nottelet, B.; Tille, J.-C.; Gurny, R.; Kalangos, A.; Möller, M.; Walpoth, B.H. Degradation and Healing Characteristics of Small-Diameter Poly( $\varepsilon$-Caprolactone) Vascular Grafts in the Rat Systemic Arterial Circulation. Circulation 2008, 118, $2563-2570$. [CrossRef]

31. Guelcher, S.A. Biodegradable Polyurethanes: Synthesis and Applications in Regenerative Medicine. Tissue Eng. Part B Rev. 2008, 14, 3-17. [CrossRef]

32. Zdrahala, R.J.; Zdrahala, I.J. Biomedical Applications of Polyurethanes: A Review of Past Promises, Present Realities, and a Vibrant Future. J. Biomater. Appl. 1999, 14, 67-90. [CrossRef]

33. Skarja, G.A.; Woodhouse, K.A. In vitro degradation and erosion of degradable, segmented polyurethanes containing an amino acid-based chain extender. J. Biomater. Sci. Polym. Ed. 2001, 12, 851-873. [CrossRef]

34. Saad, B.; Hirt, T.D.; Welti, M.; Uhlschmid, G.K.; Neuenschwander, P.; Suter, U. Development of degradable polyesterurethanes for medical applications:In vitro andin vivo evaluations. J. Biomed. Mater. Res. 1997, 36, 65-74. [CrossRef]

35. Caracciolo, P.; de Queiroz, A.; Higa, O.; Buffa, F.; Abraham, G. Segmented poly(esterurethane urea)s from novel urea-diol chain extenders: Synthesis, characterization and in vitro biological properties. Acta Biomater. 2008, 4, 976-988. [CrossRef]

36. Caracciolo, P.C.; Buffa, F.; Abraham, G.A. Effect of the hard segment chemistry and structure on the thermal and mechanical properties of novel biomedical segmented poly(esterurethanes). J. Mater. Sci. Mater. Electron. 2008, 20, 145-155. [CrossRef]

37. Abraham, G.; de Queiroz, A.A.; Román, J.S. Hydrophilic hybrid IPNs of segmented polyurethanes and copolymers of vinylpyrrolidone for applications in medicine. Biomaterials 2001, 22, 1971-1985. [CrossRef]

38. Smith, M.J.; McClure, M.J.; Sell, S.A.; Barnes, C.P.; Walpoth, B.H.; Simpson, D.G.; Bowlin, G.L. Suture-reinforced electrospun polydioxanone-elastin small-diameter tubes for use in vascular tissue engineering: A feasibility study. Acta Biomater. 2008, 4, 58-66. [CrossRef]

39. Sell, S.; McClure, M.J.; Barnes, C.P.; Knapp, D.C.; Walpoth, B.H.; Simpson, D.G.; Bowlin, G.L. Electrospun polydioxanone-elastin blends: Potential for bioresorbable vascular grafts. Biomed. Mater. 2006, 1, 72-80. [CrossRef]

40. Wang, X.; Ding, B.; Li, B. Biomimetic electrospun nanofibrous structures for tissue engineering. Mater. Today 2013, 16, $229-241$. [CrossRef]

41. Im, J.N.; Kim, J.K.; Kim, H.-K.; In, C.H.; Lee, K.Y.; Park, W.H. In vitro and in vivo degradation behaviors of synthetic absorbable bicomponent monofilament suture prepared with poly(p-dioxanone) and its copolymer. Polym. Degrad. Stab. 2007, 92, 667-674. [CrossRef]

42. Thomas, V.; Zhang, X.; Vohra, Y.K. A biomimetic tubular scaffold with spatially designed nanofibers of protein/PDS ${ }^{\circledR}$ bio-blends. Biotechnol. Bioeng. 2009, 104, 1025-1033. [CrossRef] [PubMed]

43. Goonoo, N.; Jeetah, R.; Bhaw-Luximon, A.; Jhurry, D. Polydioxanone-based bio-materials for tissue engineering and drug/gene delivery applications. Eur. J. Pharm. Biopharm. 2015, 97, 371-391. [CrossRef] [PubMed]

44. Song, S.-J.; Shin, Y.C.; Kim, S.E.; Kwon, I.K.; Lee, J.-H.; Hyon, S.-H.; Han, D.-W.; Kim, B. Aligned laminin core-polydioxanone/ collagen shell fiber matrices effective for neuritogenesis. Sci. Rep. 2018, 8, 1-11. [CrossRef] [PubMed]

45. Eslamian, M.; Khorrami, M.; Yi, N.; Majd, S.; Abidian, M.R. Electrospinning of highly aligned fibers for drug delivery applications. J. Mater. Chem. B 2018, 7, 224-232. [CrossRef]

46. Kallem, P.; Yanar, N.; Choi, H. Nanofiber-Based Proton Exchange Membranes: Development of Aligned Electrospun Nanofibers for Polymer Electrolyte Fuel Cell Applications. ACS Sustain. Chem. Eng. 2018, 7, 1808-1825. [CrossRef]

47. Yuan, H.; Zhou, Q.; Zhang, Y. Improving Fiber Alignment during Electrospinning; Elsevier: Amsterdam, The Netherlands, 2017; pp. 125-147.

48. Kim, J.I.; Hwang, T.I.; Aguilar, L.E.; Park, C.H.; Kim, C.S. A Controlled Design of Aligned and Random Nanofibers for 3D Bi-functionalized Nerve Conduits Fabricated via a Novel Electrospinning Set-up. Sci. Rep. 2016, 6, 23761. [CrossRef]

49. Sankar, S.; Sharma, C.S.; Rath, S.N.; Ramakrishna, S. Electrospun Fibers for Recruitment and Differentiation of Stem Cells in Regenerative Medicine. Biotechnol. J. 2017, 12, 1700263. [CrossRef]

50. Mousa, H.M.; Hussein, K.H.; Sayed, M.M.; El-Aassar, M.; Mohamed, I.M.; Kwak, H.-H.; Woo, H.-M.; Abdal-Hay, A. Development of biocompatible tri-layered nanofibers patches with endothelial cells for cardiac tissue engineering. Eur. Polym. J. 2020, 129, 109630. [CrossRef]

51. Beck, E.C.; Jarrell, D.K.; Lyons, A.C.; Vanderslice, E.J.; VeDepo, M.C.; Jacot, J.G. Assessment of electrospun cardiac patches made with sacrificial particles and polyurethane-polycaprolactone blends. J. Biomed. Mater. Res. Part A 2021. [CrossRef]

52. Caracciolo, P.C.; Thomas, V.; Vohra, Y.K.; Buffa, F.; Abraham, G.A. Electrospinning of novel biodegradable poly(ester urethane)s and poly(ester urethane urea)s for soft tissue-engineering applications. J. Mater. Sci. Mater. Electron. 2009, 20, $2129-2137$. [CrossRef]

53. Thomas, V.; Dean, D.R.; Jose, M.V.; Mathew, B.; Chowdhury, A.S.; Vohra, Y.K. Nanostructured Biocomposite Scaffolds Based on Collagen Coelectrospun with Nanohydroxyapatite. Biomacromolecules 2007, 8, 631-637. [CrossRef]

54. Thomas, V.; Zhang, X.; Catledge, S.A.; Vohra, Y.K. Functionally graded electrospun scaffolds with tunable mechanical properties for vascular tissue regeneration. Biomed. Mater. 2007, 2, 224-232. [CrossRef]

55. Jeffries, E.; Allen, R.A.; Gao, J.; Pesce, M.; Wang, Y. Highly elastic and suturable electrospun poly(glycerol sebacate) fibrous scaffolds. Acta Biomater. 2015, 18, 30-39. [CrossRef]

56. Chavoshnejad, P.; Razavi, M.J. Effect of the Interfiber Bonding on the Mechanical Behavior of Electrospun Fibrous Mats. Sci. Rep. 2020, 10, 7709-7710. [CrossRef] 
57. Li, H.; Zhu, C.; Xue, J.; Ke, Q.; Xia, Y. Enhancing the Mechanical Properties of Electrospun Nanofiber Mats through Controllable Welding at the Cross Points. Macromol. Rapid Commun. 2017, 38, 1600723. [CrossRef]

58. Ishikiriyama, K.; Pyda, M.; Zhang, G.; Forschner, T.; Grebowicz, J.; Wunderlich, B. Heat capacity of poly-p-dioxanone. J. Macromol. Sci. Part B 1998, 37, 27-44. [CrossRef]

59. Van Krevelen, D.W.; Te Nijenhuis, K. Properties of Polymers: Their Correlation with Chemical Structure; Their Numerical Estimation and Prediction from Additive Group Contributions; Elsevier: Amsterdam, The Netherlands, 2009; ISBN 978-0-08-091510-4.

60. Chen, C.-H.; Wei, H.-J.; Lin, W.-W.; Chiu, I.; Hwang, S.-M.; Wang, C.-C.; Lee, W.-Y.; Chang, Y.; Sung, H.-W. Porous tissue grafts sandwiched with multilayered mesenchymal stromal cell sheets induce tissue regeneration for cardiac repair. Cardiovasc. Res. 2008, 80, 88-95. [CrossRef]

61. Fujimoto, K.L.; Tobita, K.; Merryman, W.D.; Guan, J.; Momoi, N.; Stolz, D.B.; Sacks, M.S.; Keller, B.B.; Wagner, W.R. An Elastic, Biodegradable Cardiac Patch Induces Contractile Smooth Muscle and Improves Cardiac Remodeling and Function in Subacute Myocardial Infarction. J. Am. Coll. Cardiol. 2007, 49, 2292-2300. [CrossRef]

62. Henry, J.A.; Burugapalli, K.; Neuenschwander, P.; Pandit, A. Structural variants of biodegradable polyesterurethane in vivo evoke a cellular and angiogenic response that is dictated by architecture. Acta Biomater. 2009, 5, 29-42. [CrossRef]

63. Rockwood, D.N.; Akins, R.E.; Parrag, I.C.; Woodhouse, K.A.; Rabolt, J.F. Culture on electrospun polyurethane scaffolds decreases atrial natriuretic peptide expression by cardiomyocytes in vitro. Biomaterials 2008, 29, 4783-4791. [CrossRef]

64. Stankus, J.J.; Soletti, L.; Fujimoto, K.; Hong, Y.; Vorp, D.; Wagner, W.R. Fabrication of cell microintegrated blood vessel constructs through electrohydrodynamic atomization. Biomaterials 2007, 28, 2738-2746. [CrossRef] 